\title{
THE LANGUAGE-(IN)DEPENDENCE OF WRITING SKILLS: TRANSLATION AS A TOOL IN WRITING PROCESS RESEARCH AND WRITING INSTRUCTION ${ }^{1}$
}

\author{
Susanne Göpferich \\ Justus Liebig University, Giessen (Germany) \\ susanne.goepferich@anglistik.uni-giessen.de \\ Bridgit Nelezen \\ Justus Liebig University, Giessen (Germany) \\ bridgit.c.nelezen@anglistik.uni-giessen.de
}

\begin{abstract}
A pilot study was conducted in which 6 students with L1 German had to produce a German version of a text they had composed in their L2 English. The goals were to explore (a) in what respects the ability of advanced university English students to express themselves in their L2 English differs from their ability to do so in their L1 German, and (b) for which aspects of writing the implementation of translation exercises is useful as a tool to improve writing skills. The methods of data collection used were think-aloud and keystroke logging. In the analysis, special emphasis was placed on text-level errors as opposed to formal, lexical and grammatical errors. In their L1 versions, students were consistently able to avoid errors of implicitness and sense but displayed no improvements in other areas such as text coherence and functional sentence perspective. Though some of the errors could be attributed to the special requirements of the translation assignment, translation was also found to have certain advantages that make it a useful tool in writing didactics.
\end{abstract}

1. For a German version of this article, see Göpferich \& Nelezen (2013).

MonTI Special Issue - Minding Translation (2014: 117-149). ISSN 1889-4178

http://dx.doi.org/10.6035/MonTI.2014.ne1.3 


\section{Kurzreferat}

In einer Pilotstudie mit sechs fortgeschrittenen Anglistikstudierenden, deren Muttersprache Deutsch ist, wurde untersucht, in welcher Hinsicht sich deren Ausdrucksfähigkeit in ihrer L2 Englisch von derjenigen in ihrer L1 Deutsch unterscheidet. Darüber hinaus wurde erhoben, auf welche Komponenten der Textproduktionskompetenz sich Übersetzungsübungen förderlich auswirken. Die Versuchspersonen waren aufgefordert, eine deutsche Version eines von ihnen verfassten englischsprachigen Textes zu erstellen. Als Datenerhebungsmethoden kamen lautes Denken und Tastatur-Logging zum Einsatz. Die Analyse konzentriert sich auf Fehler auf der textlinguistischen Ebene im Gegensatz zu formalen, lexikalischen und Grammatikfehlern. In ihren muttersprachlichen Versionen gelang es den Versuchspersonen, Implizitheitsfehler und Sinnfehler zu vermeiden; es waren jedoch keine Verbesserungen in anderen Bereichen, wie der Textkohärenz und der funktionalen Satzperspektive, festzustellen. Obwohl einige der in den deutschsprachigen Versionen aufgetretenen Fehler eindeutig interferenzbedingt sind, zeigte sich, dass das Übersetzen für die Entwicklung von Textproduktionskompetenz bestimmte Vorteile besitzt, die es zu einer nützlichen Methode in der Schreibdidaktik machen.

Keywords: Writing vs. translating. Writing in L2. Text-level errors. Academic writing. Translation as a tool in writing instruction.

Schlagwörter: Schreiben vs. Übersetzen. Schreiben in der L2. Fehler auf der Textebene. Wissenschaftliches Schreiben. Übersetzen als Methode in der Schreibdidaktik.

Manuscript received on February 11, 2013 and accepted on September 16, 2013. 


\section{Background, literature review and research questions}

At Justus Liebig University (Giessen, Germany), as well as at many other universities, students pursuing degrees in the fields of English literature, culture and linguistics are generally required to write their term papers and final theses in English. These students are thereby immediately confronted with two concurrent challenges: the challenge of writing 'academically', which requires the students to adapt to a specific form of discourse with which they are not yet familiar, neither in their native language (L1) nor their foreign language (L2) English; and the very challenge of first having to do this in their L2. It is well known that writing, even in one's mother tongue, is a highly complex process. Therefore, writing assignments devised to foster writing competence are frequently subdivided into sub-tasks of lower complexity. Against this background, the question arises as to whether the requirement of writing academic texts in the L2, before having mastered this skill in the L1, leads to such an increase in task complexity that it overburdens students, which could have consequences reaching beyond the poorer linguistic quality that L2 compositions inevitably display: Having students write term papers in their L2 may further result in a less profound analysis of the subject matter, not to mention a less profound treatment of the L2 literature associated with the subject matter. These potential consequences of requiring students to write academic texts in their L2 are, in turn, detrimental to the epistemic function of writing.

The few studies conducted to date which have compared L1 and L2 text production have indicated that-aside from the additional lexical and grammatical challenges associated with foreign language production in general-L2 text production processes are strikingly similar to L1 text production processes. As Arndt (1987: 259) points out, "It is the constraints of the composing activity, or of the discourse type, which create problems for students writing in L2, not simply difficulties with the mechanics of the foreign language." However, Silva (1992) surveyed university students about their own L2 writing processes and observed that exactly these difficulties with lexis and grammar, as well as interference between the L1 and L2, are 
so cognitively demanding that not only the form but the content of L2 written work, and thus the epistemic function of writing, suffers. This leads to texts that are "less sophisticated" and express the ideas of the writer less effectively (Silva 1992: 33). Devine, Railey \& Bischoff (1993) compared the written compositions of 20 first-year college students in the United States, half of whom had English as their L1 and half as their L2, and came to a similar conclusion. These subjects were further required to complete a questionnaire addressing their writing processes in order to investigate the metacognitive writing models used by L1 and L2 writers. The students writing in their L2 reported having to omit certain content from their texts when they felt they did not possess the linguistic means to express this content correctly, a problem the Ll writers did not have. Unsurprisingly, the Ll essays were also rated more highly than their L2 counterparts (see also the literature review by Cumming 2001). Such findings provide support for the assumption that the epistemic benefits of writing are less pronounced when this writing takes place in the $\mathrm{L} 2$.

Several studies have established a correlation between the level of L2 competence and the varying amounts of attention given to different aspects of the writing process. From an analysis of English and French texts produced by native English-speaking university students while thinking aloud, Whalen \& Menard (1995) found that L2 writers with insufficient L2 competence tend to neglect important macro-level writing processes, including planning, evaluation, and revision, in order to focus on lower-level processes. Schoonen et al. (2003) provide further support for this finding from a study in which 281 8th-grade pupils composed texts in both their $\mathrm{Ll}$ and $\mathrm{L} 2$, the quality of which was then compared with their overall language competence:

The L2 writer may be so much involved in these kinds of 'lower-order' problems of word finding and grammatical structures that they may require too much conscious attention, leaving little or no working memory capacity free to attend to higher-level or strategic aspects of writing, such as organizing the text properly or trying to convince the reader of the validity of a certain view. The discourse and metacognitive knowledge that L2 writers are able to exploit in their L1 writing may remain unused, or underused, in their L2 writing (Schoonen et al. 2003: 171).

Roca de Larios, Manchon \& Murphy (2006) arrived at a similar interpretation after analyzing the L1 and L2 (English) texts and accompanying think-aloud protocols (TAPs) of 21 Spanish-speaking subjects who were separated into three groups based on their levels of English competence:

In L2 writing [...] the patterns emerging from the data indicate that the lower the proficiency level of the writer, the more he or she engages in compensating 
for interlanguage deficits vis-à-vis ideational or textual occupations (Roca de Larios, Manchon \& Murphy 2006: 110).

Such results warrant the assumption that L2 writing processes only strongly resemble L1 writing processes after a certain L2 competence level has been reached (cf. Kohro 2009: 16).

In order to explore whether the ability of university-level English students to express themselves in written form in their L2 differs from their ability to do so in their $\mathrm{Ll}$, and, if this is the case, in which aspects of the writing process these differences can be observed, a pilot study was conducted to explore L1 and L2 text composition. For this study, six native-speaking German students from an advanced English linguistics seminar titled "Developing Writing Skills", which was offered at the Department of English at the University of Giessen in the 2011/12 winter semester, volunteered to take part in an experiment after the seminar had ended. These six students had English as their major subject in either a master's program or a high school teacher-training program. Their task during the experiment was based on an assignment they had completed during the seminar in teams of two which required them to write a popular-science article based on one of the term papers one of the two students had written in a previous semester. The goal of the article was to inform 12th-grade pupils (of about 18 years of age) about topics that are typically dealt with in university English programs. They were explicitly instructed to write these texts so that they would be comprehensible for 12th graders and at the same time arouse interest in the topic (see assignment below). The challenge of this writing assignment was three-fold: First, the students had to reduce the length of what they had covered in their term papers to approx. 500 words and thus select only certain aspects of the term paper to be dealt with in the popular-science article. Second, they had to transform an academic text into a popular-science text. And third, they had to make sure that their popular-science text was self-contained, i.e., met the readers' expectations that were established by the author at the beginning of the text.

To provide the students with a framework of assessment criteria, they were familiarized with the Karlsruhe comprehensibility concept (Göpferich 2002) and provided a model text. After they had produced their first versions of these articles, each team of two had to exchange their article with another team and provide each other feedback, again based on the Karlsruhe comprehensibility concept, which, as they were informed, also formed the framework for the assessment of their final versions. On the basis of (a) this peer feedback, (b) the think-aloud of two students not attending the seminar 
who were required to reverbalize one article each in an optimizing manner while thinking aloud —on the method of optimizing reverbalization, see Göpferich 2006-and (c) the general remarks made by the teacher on how the articles could be improved, they were finally required to produce an optimized version of their articles to be submitted at the end of the semester as part of their portfolio, which was graded. This text production process, following the writing-is-rewriting principle, should ideally have induced the students to give their very best and thus leave few aspects of the text that would require further optimization in the subsequent translation assignment, which will be addressed in the following section.

\section{Experimental design}

During the experiment, the six students who volunteered to take part in the experiment had to produce a German version of the English text they had produced, following the instructions below: ${ }^{2}$

Please produce a German version of the English article that you composed in the seminar "Developing Writing Skills". The German version should have the same function and target group as the source text, i.e., it is supposed to provide students in their last year at school insights into topics that are dealt with in an English program at university. Please note that the text you are going to produce should not only be comprehensible but also arouse the students' interest and motivate them to go on reading.

Please also note that you do NOT have to produce a translation that is as literal as possible. If you have ideas as to how your German version can be improved with regard to, for example, its structure or individual formulations, please feel free to, and please do, put these ideas into practice.

While composing your German text, please think aloud, i.e., please utter everything that comes to your mind while working on the text. There is no time limit, and you should not rush. Instead, please work for as long as you feel is necessary to produce a version with which you are absolutely satisfied.

All the best of success and enjoy your work!

It should be noted that the participants were intentionally not instructed to 'translate' the text, but to produce a German version, because the concept of translation might have falsely led them to assume that a literal translation was required and that defects in the source text would thus have to be taken over into the target text. What the participants were rather expected to do was to produce a functional translation, which allows for deviations from the

2. The participants were provided with these instructions in German. 
source text if they contribute to making the target text more suitable for its function. The assumptions underlying these instructions were the following: The participants would experience cognitive relief due to the fact that (a) they were allowed to use their L1, in which they would have a more differentiated repertoire of linguistic means available to them to express their ideas, and that (b) the English text, due to its very existence in an externalized manner, would allow the participants to take a more critical stance towards the structure and line of argumentation of the text. If these assumptions hold true, the German texts should have a more logical structure and be more differentiated semantically than their English source texts.

During the experiments, the participants' think-aloud was recorded using the digital audio recording freeware Audacity and subsequently transcribed in XML following the modified guidelines of the Text Encoding Initiative documented in Göpferich (2010). Their writing processes were furthermore registered using the keystroke-logging software Translog 2006.

\section{Data analysis}

The first level of analysis concerned the differences in linguistic accuracy in the L1 and L2 texts. For this, the English source texts and the German target texts were marked according to the error classification scheme summarized in table 1.

Every error identified in the English and German texts was highlighted and annotated with a corresponding error tag (for the entire annotated corpus, see Göpferich \& Nelezen 2012). To reduce subjectivity, three raters who were already familiar with the error classification scheme marked the texts separately; discrepancies among the raters' marks were discussed and reconciled thereafter.

In order to ensure consistent error classification, errors were always categorized with the largest possible granularity. This means that the attempt was made to categorize errors with regard to the smallest linguistic unit involved in the error, or what could be considered the most elementary linguistic category. Once this was pinpointed, the errors were always classified under their primary cause and/or most specific error type. For example, implicitness errors also tend to cause coherence problems and can thus also be considered coherence errors. The primary cause of this error type, however, is implicitness and not coherence; therefore, they were always marked as such and not as text-coherence errors.

In addition to the classification of error type, the process-oriented data collected (i.e., the think-aloud protocols and keystroke log files) were 
analyzed in order to determine whether the subjects reflected upon errors. Errors were considered to have been reflected upon when at least one of the following occurred:

- at least one alternative was generated for the erroneous expression(s) as documented in the think-aloud protocols or the log files,

- at least one pause of more than 5 seconds occurred in connection with the erroneous expression(s), or

- a problem was stated explicitly in the think-aloud. ${ }^{3}$

\begin{tabular}{|l|l|}
\hline Error category & Description / Example \\
\hline Formal errors & \multicolumn{2}{|l|}{} \\
\hline punctuation & $\begin{array}{l}\text { missing or wrong punctuation mark; if both a comma at the } \\
\text { beginning and at the end of an insertion are missing, this is counted } \\
\text { as only one error; repeated comma errors are counted as repetition } \\
\text { errors only if they have the same cause }\end{array}$ \\
\hline spelling & $\begin{array}{l}\text { spelling mistake which is not an obvious typo (e.g., Tauchen Sie das } \\
\text { Gehäuse ihres Gerätes nie unter Wasser.) }\end{array}$ \\
\hline formatting & $\begin{array}{l}\text { line break where there should be none (the participants were not } \\
\text { required to do any other formatting in the text); italics where there } \\
\text { should be none and vice versa }\end{array}$ \\
\hline Lexical errors & $\begin{array}{l}\text { use of words and phrases which do not express the intended } \\
\text { meaning either denotatively (semantic: denotation) or connotatively } \\
\text { (semantic: connotation). This category includes the use of a wrong } \\
\text { register at word level (semantic: connotation). Note: Blendings and } \\
\text { wrong illocutionary indicators are classified as separate categories. } \\
\text { See also "collocation" and "modality/illocution". }\end{array}$ \\
\hline semantic & $\begin{array}{l}\text { wrong collocation (e.g., schnelle Geschwindigkeit instead of hohe } \\
\text { Geschwindigkeit). This category only includes cases in which the } \\
\text { meanings of the words used are appropriate but in which these } \\
\text { words cannot be combined for other reasons, such as idiomaticity or } \\
\text { convention. }\end{array}$ \\
\hline collocation & $\begin{array}{l}\text { error caused by melding together parts of linguistic units or } \\
\text { constructions which enter working memory simultaneously }\end{array}$ \\
\hline preposition & \begin{tabular}{l} 
use of a wrong preposition (see also "other grammar") \\
\hline
\end{tabular} \\
\hline
\end{tabular}

3. The alternatives generated or the problem stated explicitly must refer directly to the respective error category to be considered reflected upon. 


\begin{tabular}{|c|c|}
\hline $\begin{array}{l}\text { modality/ } \\
\text { illocution }\end{array}$ & $\begin{array}{l}\text { wrong illocutionary indicator, such as sollte (recommendation) } \\
\text { instead of muss (instruction). Strictly speaking, these errors could } \\
\text { also be classified as idiomaticity/genre errors (genre-convention } \\
\text { errors) because the illocutionary indicators to be used may be } \\
\text { determined by the genre conventions (see Göpferich 1995: } 308 \mathrm{ff} .) \text {. }\end{array}$ \\
\hline redundancy & $\begin{array}{l}\text { superfluous repetition of meaning components, ideas, statements or } \\
\text { words including tautologies (see also "text coherence") }\end{array}$ \\
\hline \multicolumn{2}{|c|}{ Grammatical errors } \\
\hline tense & use of wrong tense \\
\hline aspect & use of wrong aspect \\
\hline $\begin{array}{l}\text { case, number, } \\
\text { agreement }\end{array}$ & $\begin{array}{l}\text { use of wrong case or grammatical number, mostly after prepositions } \\
\text { or in appositions; agreement error }\end{array}$ \\
\hline $\operatorname{mood}$ & wrong mood, e.g., in indirect speech \\
\hline voice & active voice instead of passive voice and vice versa \\
\hline word form & $\begin{array}{l}\text { morphologically wrong word form, such as adjectives instead of } \\
\text { adverbs and vice versa; wrong formation of past tense forms; use of } \\
\text { expressions which do not exist; use of words from another language } \\
\text { which cannot be expected to be understood in the target culture, } \\
\text { etc. }\end{array}$ \\
\hline syntax & $\begin{array}{l}\text { syntactic error; constructions which are hard to understand } \\
\text { due to their length, long parentheses, etc.; utterances which } \\
\text { are grammatically correct but which would only make sense if } \\
\text { additional lexical elements were inserted, e.g., The few utterances } \\
\text { could not be categorized as either one of the two models. Comment: } \\
\text { For this utterance to make sense it would have to be reformulated } \\
\text { into: The few utterances could not be categorized as belonging to either } \\
\text { one of the two models. }\end{array}$ \\
\hline valency & $\begin{array}{l}\text { missing actant; use of a lexical element that requires further } \\
\text { specification; applicable also to nominalised verbs, e.g., Aufenthalt } \\
\text { (from sich aufhalten in), where the indication of a place is required }\end{array}$ \\
\hline $\begin{array}{l}\text { specifier (article } \\
\text { or determiner) }\end{array}$ & $\begin{array}{l}\text { use of a determiner, e.g., an article, where there should be none; use } \\
\text { of a definite article where an indefinite article should be used; etc. }\end{array}$ \\
\hline infinitive & $\begin{array}{l}\text { grammmatically wrong use of an infinitive construction (e.g., Das } \\
\text { Wetter war zu schlecht, um schwimmen zu gehen.) }\end{array}$ \\
\hline $\begin{array}{l}\text { secondary } \\
\text { subjectivization }\end{array}$ & $\begin{array}{l}\text { use of verbs expressing human actions in connection with non- } \\
\text { human subjects (possible in English but rare in German); e.g., This } \\
\text { book describes (correct) vs. Dieses Buch beschreibt (wrong) }\end{array}$ \\
\hline other grammar & $\begin{array}{l}\text { other grammatical errors, such as the use of a prepositional phrase } \\
\text { instead of a genitive and vice versa (e.g., von seinem Vater instead of } \\
\text { seines Vaters) }\end{array}$ \\
\hline
\end{tabular}




\begin{tabular}{|c|c|}
\hline \multicolumn{2}{|c|}{ Text-level errors } \\
\hline text coherence & $\begin{array}{l}\text { incoherent text segments, e.g., logically wrong connection of clauses } \\
\text { and sentences by the use of semantically inappropriate conjunctions; } \\
\text { use of wrong pronouns; sentence not related to its context; referent } \\
\text { unclear; missing second part of correlative (two-part) conjunctions; } \\
\text { repetition of a noun phrase where a pronoun would be sufficient }\end{array}$ \\
\hline sense & $\begin{array}{l}\text { incomprehensible or nonsensical section longer than a phrase } \\
\text { (otherwise it is counted as a semantic error), contradictory } \\
\text { statements }\end{array}$ \\
\hline implicitness & $\begin{array}{l}\text { too much information left implicit, e.g., author does not express } \\
\text { something to which a conjunction, etc. refers (e.g., There are three } \\
\text { types of birch trees. Therefore, I will describe only one. Here, therefore } \\
\text { refers to a sentence that was left implicit, i.e., I cannot cover them } \\
\text { all.) }\end{array}$ \\
\hline $\begin{array}{l}\text { functional } \\
\text { sentence } \\
\text { perspective } \\
\text { (FSP) }\end{array}$ & wrong topic-comment structure (theme/rheme) \\
\hline rhetoric & $\begin{array}{l}\text { loss of communicative emphasis or effect (e.g., replacing a poem by } \\
\text { a mere description of its content); literal repetitions (see, however, } \\
\text { "redundancy" and "text coherence") }\end{array}$ \\
\hline \multicolumn{2}{|l|}{ Other } \\
\hline $\begin{array}{l}\text { idiomaticity/ } \\
\text { genre }\end{array}$ & $\begin{array}{l}\text { unidiomatic expression which does not lead to a change of meaning } \\
\text { but may make the text hard to understand and betray that it is a } \\
\text { translation in a negative sense; use of expressions which do not } \\
\text { conform to genre conventions (e.g., Das Bild ist kein Zufallstreffer. } \\
\text { instead of Das Bild ist kein Schnappschuss. and Anfangend mit Namen } \\
\text { as a title.) }\end{array}$ \\
\hline $\begin{array}{l}\text { cultural } \\
\text { specificity }\end{array}$ & $\begin{array}{l}\text { missing adaptation to the target culture or missing cultural } \\
\text { neutralisation }\end{array}$ \\
\hline
\end{tabular}

Table 1. Error classification scheme.

The number of errors reflected upon by the subjects is of interest because it provides insight into the subjects' own awareness of the problematic aspects of their texts. When a subject reflected on an error but was still unable to circumvent it, i.e., generate and subsequently choose a correct alternative, it can be assumed that the subject lacked competence in the area of text evaluation but still displayed a certain degree of problem awareness. In contrast, when a subject made an error without reflecting on it, this indicates a lack of problem awareness. The latter shortcoming, i.e., a lack of problem awareness, 
is assumed to be more difficult to address didactically than lacking evaluation competence.

The total number of linguistic errors in the texts, while a useful means of comparison, cannot by itself serve as an exhaustive measure of overall text quality. For this reason, a qualitative comparison of the source and target texts was also conducted in which the improvements and deteriorations with respect to the above error scheme were identified and analyzed. The results of this comparison will be illustrated with excerpts in section 4. Finally, as a further text quality measure, the assessment scheme depicted in table 2, based on the Karlsruhe comprehensibility concept, was also implemented.

\section{Results and discussion}

The contrastive analysis in which the source and target texts were assessed according to the Karlsruhe comprehensibility concept yielded the following results: No noteworthy difference in the scores of the English texts and the German texts could be observed for any of the subjects. In other words, no significant improvements or deteriorations on the textual macro-level, i.e., the level which comprises more than two adjacent sentences, could be observed between the English and German text versions. Out of a maximum score of 45 points, the discrepancy between the source-text- and target-text scores was only found to be between +4 and -2 points; in three cases, the text quality on a macro-level of the English texts was slightly better than that of their German counterparts, and in the three remaining cases, the opposite trend was observed (for the complete results, see Göpferich \& Nelezen 2012). This lack of significant change from the English to the German texts arose from the manner in which the subjects composed their German texts: Instead of attempting to make changes on a macro-level, the subjects primarily transferred the contents of the source texts into the target texts on a sentence-to-sentence basis and thus focused on the micro-level, i.e., the level of neighboring sentences. The changes made to the texts at this level had little overall effect on macro-level issues such as the functional adequacy of the texts and their appropriateness for their audience. It should also be noted, however, that the similarity of the L1 and L2 texts on the macro-level may simply signal unawareness on the part of the subjects concerning the structural shortcomings of their texts, both in their L2 and in their L1. If the latter is the case, this would confirm Arndt's (1987) assumption that L1 and L2 writing processes are, on a global level, very similar. The data basis of the analyses presented in this article, however, is too small to draw such conclusions. 


\begin{tabular}{|c|c|c|c|c|c|}
\hline & \multicolumn{5}{|c|}{ Score } \\
\hline Criteria* & 4 & 3 & 2 & 1 & 0 \\
\hline \multicolumn{6}{|c|}{ Communicative function } \\
\hline $\begin{array}{l}\text { To what extent does } \\
\text { the article have a } \\
\text { consistent commu- } \\
\text { nicative function? }\end{array}$ & fully & $\begin{array}{l}\text { to a great } \\
\text { extent }\end{array}$ & $\begin{array}{l}\text { to some } \\
\text { extent }\end{array}$ & $\begin{array}{l}\text { to little } \\
\text { extent }\end{array}$ & not at all \\
\hline \multicolumn{6}{|l|}{ Audience } \\
\hline $\begin{array}{l}\text { To what extent does } \\
\text { the article take its } \\
\text { audience's require- } \\
\text { ments and interests } \\
\text { into account? }\end{array}$ & fully & $\begin{array}{l}\text { to a great } \\
\text { extent }\end{array}$ & $\begin{array}{l}\text { to some } \\
\text { extent }\end{array}$ & $\begin{array}{l}\text { to little } \\
\text { extent }\end{array}$ & not at all \\
\hline \multicolumn{6}{|c|}{ Mental denotation model (content) } \\
\hline $\begin{array}{l}\text { Is the mental } \\
\text { denotation model } \\
\text { adequate (super- } \\
\text { fluous elements, } \\
\text { relevant information } \\
\text { missing)? }\end{array}$ & fully & $\begin{array}{l}\text { a few } \\
\text { super- } \\
\text { fluous or } \\
\text { missing } \\
\text { elements }\end{array}$ & $\begin{array}{l}\text { many } \\
\text { super- } \\
\text { fluous or } \\
\text { missing } \\
\text { elements }\end{array}$ & $\begin{array}{l}\text { so many } \\
\text { that } \\
\text { compre- } \\
\text { hension } \\
\text { greatly } \\
\text { suffers }\end{array}$ & $\begin{array}{l}\text { so many } \\
\text { that text is } \\
\text { incompre- } \\
\text { hensible }\end{array}$ \\
\hline \multicolumn{6}{|c|}{ Structure (argumentation) } \\
\hline $\begin{array}{l}\text { To what extent is the } \\
\text { article structured } \\
\text { logically at the } \\
\text { macro-level? }\end{array}$ & fully & $\begin{array}{l}\text { to a great } \\
\text { extent }\end{array}$ & $\begin{array}{l}\text { to some } \\
\text { extent }\end{array}$ & $\begin{array}{l}\text { to little } \\
\text { extent }\end{array}$ & not at all \\
\hline $\begin{array}{l}\text { Is the article } \\
\text { self-contained (clear } \\
\text { beginning and clear } \\
\text { ending)? }\end{array}$ & & & yes & $\begin{array}{l}\text { to some } \\
\text { extent }\end{array}$ & no \\
\hline $\begin{array}{l}\text { To what extent } \\
\text { is the article } \\
\text { structured logically } \\
\text { at the micro-level } \\
\text { (functional sen- } \\
\text { tence perspective, } \\
\text { connectors)? }\end{array}$ & fully & $\begin{array}{l}\text { to a great } \\
\text { extent }\end{array}$ & $\begin{array}{l}\text { to some } \\
\text { extent }\end{array}$ & $\begin{array}{l}\text { to little } \\
\text { extent }\end{array}$ & not at all \\
\hline \multicolumn{6}{|l|}{ Simplicity } \\
\hline $\begin{array}{l}\text { To what extent are } \\
\text { the lexical elements } \\
\text { and grammatical } \\
\text { constructions } \\
\text { adequate? }\end{array}$ & fully & $\begin{array}{l}\text { to a great } \\
\text { extent }\end{array}$ & $\begin{array}{l}\text { to some } \\
\text { extent }\end{array}$ & $\begin{array}{l}\text { to little } \\
\text { extent }\end{array}$ & not at all \\
\hline
\end{tabular}




\begin{tabular}{|c|c|c|c|c|c|}
\hline \multicolumn{6}{|l|}{ Motivation } \\
\hline $\begin{array}{l}\text { To what extent } \\
\text { does the article } \\
\text { attract and hold the } \\
\text { audience's attention } \\
\text { (motivation)? }\end{array}$ & adequately & $\begin{array}{l}\text { to a great } \\
\text { extent }\end{array}$ & somewhat & vaguely & not at all \\
\hline $\begin{array}{l}\text { Does the article have } \\
\text { an attractive title? }\end{array}$ & & & yes & somewhat & no \\
\hline \multicolumn{6}{|l|}{ Correctness } \\
\hline $\begin{array}{l}\text { To what extent is } \\
\text { the article correct } \\
\text { content-wise? }\end{array}$ & & throughout & $\begin{array}{l}\text { contains } \\
\text { minor } \\
\text { errors } \\
\end{array}$ & $\begin{array}{l}\text { contains } \\
\text { major } \\
\text { errors }\end{array}$ & $\begin{array}{l}\text { completely } \\
\text { wrong }\end{array}$ \\
\hline $\begin{array}{l}\text { To what extent is the } \\
\text { article correct at the } \\
\text { language level? }\end{array}$ & \multicolumn{5}{|c|}{$\begin{array}{l}5 \text { points (perfect) }-0 \text { points (so poor that it is largely } \\
\text { incomprehensible) }\end{array}$} \\
\hline \multicolumn{6}{|l|}{ Concision } \\
\hline $\begin{array}{l}\text { Are ideas expressed } \\
\text { in a concise manner? }\end{array}$ & $\begin{array}{l}\text { concise } \\
\text { text }\end{array}$ & $\begin{array}{l}\text { only few } \\
\text { wordy } \\
\text { expres- } \\
\text { sions or } \\
\text { clumsy } \\
\text { construc- } \\
\text { tions } \\
\end{array}$ & $\begin{array}{l}\text { many } \\
\text { wordy } \\
\text { expres- } \\
\text { sions or } \\
\text { clumsy } \\
\text { construc- } \\
\text { tions }\end{array}$ & very many & $\begin{array}{l}\text { so many } \\
\text { that text is } \\
\text { difficult to } \\
\text { read }\end{array}$ \\
\hline \multicolumn{6}{|l|}{ Perceptibility } \\
\hline $\begin{array}{l}\text { Is the formatting and } \\
\text { layout adequate? }\end{array}$ & & & fully & $\begin{array}{l}\text { with a few } \\
\text { exceptions }\end{array}$ & $\begin{array}{l}\text { with many } \\
\text { exceptions }\end{array}$ \\
\hline \multicolumn{6}{|c|}{ Mental convention model (style) } \\
\hline Is the style adequate? & fully & $\begin{array}{l}\text { to a great } \\
\text { extent }\end{array}$ & $\begin{array}{l}\text { to some } \\
\text { extent }\end{array}$ & $\begin{array}{l}\text { to little } \\
\text { extent }\end{array}$ & inadequate \\
\hline \multicolumn{6}{|l|}{ Media } \\
\hline $\begin{array}{l}\text { Are the media } \\
\text { selected adequately? }\end{array}$ & & & fully & $\begin{array}{l}\text { with a few } \\
\text { exceptions }\end{array}$ & $\begin{array}{l}\text { with many } \\
\text { exceptions }\end{array}$ \\
\hline \multicolumn{6}{|l|}{ Special requirements? } \\
\hline $\begin{array}{l}\text { To what extent have } \\
\text { special requirements } \\
\text { (legal, formal, etc.) } \\
\text { been taken into } \\
\text { account? }\end{array}$ & & & fully & $\begin{array}{l}\text { with a few } \\
\text { exceptions }\end{array}$ & $\begin{array}{l}\text { with many } \\
\text { exceptions }\end{array}$ \\
\hline
\end{tabular}

Table 2. Assessment scheme based on the Karlsruhe comprehensibility concept (* if a criterion is not applicable, e.g., because the correctness on the content-level cannot be assessed by the investigators, $n$. — for not applicable - is indicated). 
Table 3 provides an overview of the linguistic errors made by every subject in their source and target texts, and further reports on the number of reflected errors in the German texts. The results in table 3 show that, contrary to the assumptions stated in section 2, more errors were made in the German texts (227 total errors) than in the English texts (186 total errors). If the error class "Other", in which no difference was observed between the English and German texts, is disregarded, the number of errors in the German texts is actually higher in every category (formal errors, lexical errors, and grammatical errors) with the exception of text-level errors, of which there were fewer in the German texts. There are many possible reasons for such a result, two of which will be discussed here.

First, the high number of errors in the German texts might have been caused by the translation task itself. Though the term 'translation' was deliberately avoided in the assignment, it is likely that many of the errors were caused by either L2 interference or a strong degree of fixedness on source-text formulations. ${ }^{4}$ This is also supported by the fact that students of translation tend to produce errors arising from interference and fixedness at the beginning of their translation training, errors that tend to occur in lesser frequency as translation competence develops. Considering that the subjects in this study had little or no experience in translation, it is reasonable to assume that their behavior greatly resembled that of translation novices. In remaining as close to the source text as possible, the subjects may have been implementing a type of cognitive relief strategy: In order to save cognitive capacity for other processes (such as generating appropriate German renderings of English terms), they may have avoided diverting greatly from the source text, especially on the macro-level.

Second, the higher number of errors in the German texts could have reasons independent of the translation task. It is reasonable to assume that the subjects may simply display certain shortcomings in the areas of, for example, German punctuation rules, word choice, and grammar. One indication of this is that several subjects expressed their desire to use reference materials such as a dictionary or the internet to assist them in finding appropriate expressions and synonyms, a desire which was not granted during this particular experiment. In light of these observations, an analysis focusing specifically on the Ll errors and their causes would be promising, especially in the paradigm of Situated or Embedded Cognition from the cognitive sciences, which

4. For more about the phenomenon of fixedness in psychology, see Duncker (1945); for fixedness in translation, see Mandelblit (1994). 
postulates that an individual's particular work environment and conditions have a decisive influence on his or her cognitive processes. As a consequence, taking subjects out of their usual work environments can be expected to have negative effects on the results of their work (cf. Hutchins 1995; Clark 1998, 2008; Clark \& Chalmers 1998). ${ }^{5}$ For reasons of space, this cannot be addressed further in this article.

Further interesting insights into L1 and L2 text composition processes can be gained when closely examining the results regarding the text-level errors, the only category in which an improvement from English to German was observed (45 errors in the English texts versus 39 errors in the German ones). When examining these errors for individual subjects, we see that four of the six subjects performed better in their German texts than in their English texts (see Table 3). This result supports the assumption stated in section 2 that students, at least at the text level, are better able to express themselves in their L1 than in their L2 and seem to take a more critical stance towards their texts' logical structure and argumentation. Another possible explanation for this result is that the subjects may have been able to improve upon the logical structure and argumentation of their German texts because both were already provided in the English texts, offering them a certain amount of cognitive relief by enabling them to carry over the structure and content into the German texts.

\begin{tabular}{|l|c|c|c|c|c|c|c|c|c|c|c|c|c|c|c|c|c|c|c|c|c|}
\hline & \multicolumn{3}{|c|}{ FrSc } & \multicolumn{3}{|c|}{ InMa } & \multicolumn{3}{|c|}{ JeCr } & \multicolumn{3}{|c|}{ LaRe } & \multicolumn{3}{|c|}{ LaSe } & \multicolumn{3}{c|}{ RiDö } & \multicolumn{3}{c|}{ Totals } \\
\hline Error category & E & G & R & E & G & R & E & G & R & E & G & R & E & G & R & E & G & R & E & G & R \\
\hline Formal errors & 5 & 8 & 0 & 3 & 7 & 0 & 5 & 13 & 3 & 9 & 13 & 2 & 3 & 4 & 0 & 2 & 13 & 0 & 27 & 58 & 5 \\
\hline punctuation & 4 & 6 & 0 & 0 & 3 & 0 & 4 & 10 & 2 & 7 & 8 & 1 & 3 & 3 & 0 & 2 & 11 & 0 & 20 & 41 & 3 \\
\hline spelling & 1 & 2 & 0 & 3 & 4 & 0 & 1 & 3 & 1 & 2 & 5 & 1 & 0 & 1 & 0 & 0 & 2 & 0 & 7 & 17 & 2 \\
\hline formatting & $\mathrm{n}$ & $\mathrm{n}$ & $\mathrm{n}$ & $\mathrm{n}$ & $\mathrm{n}$ & $\mathrm{n}$ & $\mathrm{n}$ & $\mathrm{n}$ & $\mathrm{n}$ & $\mathrm{n}$ & $\mathrm{n}$ & $\mathrm{n}$ & $\mathrm{n}$ & $\mathrm{n}$ & $\mathrm{n}$ & $\mathrm{n}$ & $\mathrm{n}$ & $\mathrm{n}$ & $\mathrm{n}$ & $\mathrm{n}$ & $\mathrm{n}$ \\
\hline Lexical errors & 17 & 20 & 6 & 8 & 16 & 11 & 17 & 20 & 9 & 12 & 6 & 1 & 5 & 11 & 7 & 6 & 5 & 2 & 65 & 78 & 36 \\
\hline semantic & 7 & 16 & 6 & 8 & 16 & 11 & 7 & 15 & 8 & 8 & 5 & 1 & 4 & 11 & 7 & 2 & 4 & 2 & 36 & 67 & 35 \\
\hline collocation & 2 & 1 & 0 & 0 & 0 & 0 & 2 & 2 & 1 & 0 & 1 & 0 & 0 & 0 & 0 & 1 & 0 & 0 & 5 & 4 & 1 \\
\hline blending & 0 & 0 & 0 & 0 & 0 & 0 & 0 & 0 & 0 & 0 & 0 & 0 & 0 & 0 & 0 & 0 & 0 & 0 & 0 & 0 & 0 \\
\hline preposition & 3 & 0 & 0 & 0 & 0 & 0 & 3 & 2 & 0 & 2 & 0 & 0 & 1 & 0 & 0 & 2 & 1 & 0 & 11 & 3 & 0 \\
\hline modality/ illocution & 1 & 1 & 0 & 0 & 0 & 0 & 1 & 0 & 0 & 0 & 0 & 0 & 0 & 0 & 0 & 1 & 0 & 0 & 3 & 1 & 0 \\
\hline
\end{tabular}

5. If the high number of errors is due to the subjects' not being allowed to use reference materials, this would indicate that the subjects lack problem-avoidance strategies. 


\begin{tabular}{|c|c|c|c|c|c|c|c|c|c|c|c|c|c|c|c|c|c|c|c|c|c|}
\hline redundancy & 4 & 2 & 0 & 0 & 0 & 0 & 4 & 1 & 0 & 2 & 0 & 0 & 0 & 0 & 0 & 0 & 0 & 0 & 10 & 3 & 0 \\
\hline Grammatical errors & 10 & 12 & 5 & 6 & 2 & 1 & 10 & 15 & 4 & 8 & 6 & 2 & 6 & 8 & 4 & 5 & 5 & 2 & 45 & 48 & 18 \\
\hline tense & 1 & 0 & 0 & 2 & 1 & 1 & 1 & 1 & 0 & 1 & 1 & 0 & 1 & 3 & 2 & 0 & 0 & 0 & 6 & 6 & 3 \\
\hline aspect & 1 & 0 & 0 & 0 & 0 & 0 & 1 & 0 & 0 & 0 & 0 & 0 & 2 & 0 & 0 & 1 & 0 & 0 & 5 & 0 & 0 \\
\hline case, number, agreement & 1 & 4 & 2 & 1 & 0 & 0 & 1 & 3 & 1 & 1 & 2 & 1 & 0 & 0 & 0 & 0 & 2 & 1 & 4 & 11 & 5 \\
\hline $\operatorname{mood}$ & 0 & 0 & 0 & 0 & 0 & 0 & 0 & 0 & 0 & 0 & 0 & 0 & 0 & 1 & 1 & 0 & 1 & 0 & 0 & 2 & 1 \\
\hline voice & 0 & 0 & 0 & 0 & 0 & 0 & 0 & 0 & 0 & 0 & 0 & 0 & 0 & 0 & 0 & 1 & 0 & 0 & 1 & 0 & 0 \\
\hline word form & 1 & 0 & 0 & 0 & 0 & 0 & 1 & 2 & 1 & 1 & 0 & 0 & 0 & 1 & 0 & 0 & 1 & 1 & 3 & 4 & 2 \\
\hline syntax & 2 & 2 & 1 & 2 & 0 & 0 & 2 & 3 & 1 & 3 & 1 & 0 & 0 & 0 & 0 & 0 & 0 & 0 & 9 & 6 & 2 \\
\hline valency & 0 & 0 & 0 & 0 & 0 & 0 & 0 & 0 & 0 & 0 & 0 & 0 & 0 & 2 & 1 & 0 & 0 & 0 & 0 & 2 & 1 \\
\hline specifier & 4 & 3 & 1 & 1 & 0 & 0 & 4 & 2 & 1 & 2 & 1 & 1 & 3 & 1 & 0 & 2 & 1 & 0 & 16 & 8 & 3 \\
\hline infinitive & 0 & 0 & 0 & 0 & 0 & 0 & 0 & 0 & 0 & 0 & 0 & 0 & 0 & 0 & 0 & 0 & 0 & 0 & 0 & 0 & 0 \\
\hline secondary subjectivization & 0 & 2 & 1 & 0 & 1 & 0 & 0 & 1 & 0 & 0 & 1 & 0 & 0 & 0 & 0 & 0 & 0 & 0 & 0 & 5 & 1 \\
\hline other grammar & 0 & 1 & 0 & 0 & 0 & 0 & 0 & 3 & 0 & 0 & 0 & 0 & 0 & 0 & 0 & 1 & 0 & 0 & 1 & 4 & 0 \\
\hline Text-level errors & 6 & 10 & 9 & 2 & 1 & 0 & 6 & 9 & 1 & 21 & 11 & 3 & 8 & 7 & 1 & 2 & 1 & 0 & 45 & 39 & 14 \\
\hline text coherence & 2 & 5 & 4 & 0 & 0 & 0 & 2 & 4 & 1 & 9 & 7 & 2 & 3 & 3 & 0 & 2 & 0 & 0 & 18 & 19 & 7 \\
\hline sense & 0 & 1 & 1 & 1 & 0 & 0 & 0 & 0 & 0 & 8 & 2 & 0 & 1 & 1 & 0 & 0 & 0 & 0 & 10 & 4 & 1 \\
\hline implicitness & 2 & 0 & 0 & 0 & 0 & 0 & 2 & 2 & 0 & 0 & 0 & 0 & 3 & 0 & 0 & 0 & 0 & 0 & 7 & 2 & 0 \\
\hline FSP * & 0 & 2 & 2 & 1 & 1 & 0 & 0 & 1 & 0 & 1 & 0 & 0 & 1 & 2 & 1 & 0 & 0 & 0 & 3 & 6 & 3 \\
\hline rhetoric & 2 & 2 & 2 & 0 & 0 & 0 & 2 & 2 & 0 & 3 & 2 & 1 & 0 & 1 & 0 & 0 & 1 & 0 & 7 & 8 & 3 \\
\hline Other & 0 & 1 & 1 & 2 & 1 & 0 & 0 & 2 & 1 & 1 & 0 & 0 & 0 & 0 & 0 & 1 & 0 & 0 & 4 & 4 & 2 \\
\hline $\begin{array}{l}\text { idiomaticity/genre } \\
\text { conventions }\end{array}$ & 0 & 1 & 1 & 1 & 0 & 0 & 0 & 2 & 1 & 1 & 0 & 0 & 0 & 0 & 0 & 1 & 0 & 0 & 3 & 3 & 2 \\
\hline cultural specificity & 0 & 0 & 0 & 1 & 1 & 0 & 0 & 0 & 0 & 0 & 0 & 0 & 0 & 0 & 0 & 0 & 0 & 0 & 1 & 1 & 0 \\
\hline Totals & 38 & 51 & 21 & 21 & 27 & 12 & 38 & 59 & 18 & 51 & 36 & 8 & 22 & 30 & 12 & 16 & 24 & 4 & 186 & 227 & 75 \\
\hline
\end{tabular}

Table 3. Number of errors found in the English (E) and German (G) texts and number of reflected errors (R) in the German texts (* Functional Sentence Perspective).

The subjects did not, however, make improvements from English to German in every text-level subcategory. While a notable improvement can be witnessed in the subcategories of sense and implicitness, the point values for the subcategories "text coherence" and "rhetoric" differed by only one point. There was even an increase in functional sentence perspective (FSP) errors from the English to the German texts ( 3 errors in English, 6 errors in German). The lattermost result is likely due to the differences in English and German in inflectional morphology and hence the ways in which they can obtain certain topic-comment structures. Whereas in English, the S-V-O 
word order is relatively fixed, the rich inflectional morphology of the German language allows for a greater degree of syntactic flexibility. Nonetheless, the subjects often seem to have simply imitated the word order used in their English source texts instead of finding an appropriate German alternative. The extent to which these German FSP errors were induced by fixedness on the English syntactic structures will be more closely addressed in section 4.4.

The results regarding errors reflected upon in the German texts are also remarkable. The subjects only reflected upon 9\% of formal errors (e.g., punctuation, spelling). In contrast, lexical errors were reflected upon most frequently (46\%), followed by grammar errors (38\%). Finally, text-level errors were reflected upon in $36 \%$ of all cases (though none of the implicitness errors were).

The fact that the percentage of errors reflected upon was lower for errors on the text-level than for those in the categories of lexis and grammar could be due to a greater degree of fixedness on these latter categories. In other words, it appears that the subjects orientated themselves greatly on the surface structures of the English source texts when it came to lexis and grammar, and had to make a deliberate effort (i.e., had to reflect upon these structures) to free themselves from this fixedness and produce appropriate German expressions. For this to occur on the text-level, in contrast, a smaller degree of concerted effort seems to have been necessary. In these cases, the improvements on the text level likely occurred because the subjects were able to focus on the logical relations between the ideas in their texts, not simply the way they were explicitly expressed in English. The relative degrees of fixedness depending on error types will be discussed in greater detail in section 4.1.

The changes made on the text level are those that most greatly affect the structural and argumentative quality of the texts. For this reason, the analysis that follows will focus on these text-level errors in a contrastive manner, specifically the errors in the categories of text coherence, sense, implicitness and FSP. ${ }^{6}$

\subsection{Text-coherence errors}

With 18 errors in English and 19 in German, text-coherence errors form the largest subcategory among the text-level errors, accounting for $44 \%$ of all

6 . Because the types of rhetorical errors vary greatly, they will not be addressed here but can be found in Göpferich \& Nelezen (2012). 
text-level errors. ${ }^{7}$ Though one might assume that the errors in English were simply carried over into the German texts, only four of the 18 errors in the English texts were actually transferred to their German counterparts. This means that the subjects were able to avoid 14 of the 18 (English) errors in their German texts, a seemingly impressive improvement, but that they also made 15 new errors in their German texts that were not the result of direct transfer. Excerpts le (English) and lg (German) below illustrate errors which occurred in the same place in both the English source text and German target text, but the error types that occurred in these places differ: In the English text, the coherence error arises from the use of an illogical connector (adversative instead of additive), whereas in the German text, though a logical connector (sowohl - als auch) is used, the second part of this correlative conjunction (und instead of als auch) does not fit to the first one: ${ }^{8}$

(1e) By using contemporary modern [sic] elements like [sic] cubism and incorporating typical African elements, Douglas was able to create an unequal [sic] African American art style, [sic] that was able to address modern issues, but also represent the [sic] common identity. ${ }^{9}$ (JeCr)

(1g) Indem er Elemente des Kubismus und typisch Afro-Amerikanische [sic] Symbole in seiner Kunst vereinte, hat er einen neuen Afro-Amerikanischen [sic] Kunststil entwickelt [sic], der sowohl moderne [sic] Themen portraitiert [sic] und die Identität der Afro-Amerikaner repräsentiert.

In addition to illogical connectors and the inconsistent use of correlative conjunctions, the following text-coherence error types were indentified in the German and English texts:

Reference to an antecedent by means of a noun that does not fit:

(2g) Der Hauptgrund lag in der Versklavung von afrikanischen Amerikanern [sic] in der Vergangenheit [sic] und deren geringen [sic] Ansehen und [sic] Stellung in der damaligen [sic] Gesellschaft. Dieser Rassismus bestand nahe zu [sic] unverändert bis in die 1920er Jahre und führte

7. The other text-level errors, e.g., sense and implicitness, also carry negative effects on text coherence, but, as stated in section 3, they were not classified as such because text coherence was not considered to be the primary error.

8. The error in English could also be considered an inconsistent use of the correlative conjunction not only..., but also..., a likely assumption considering the similar error made in the corresponding German version.

9. The errors illustrated in this article are italicized, while other errors that occurred in the shown excerpts are marked with [sic]. Since the errors marked with [sic] are not dealt with in this article, it is not necessary for the reader to understand why they are marked. 
zu einem zugespitzten rassistischem [sic] Denken und zu rassistisch motivierter Gewalt. (FrSc) ${ }^{10}$

Use of a full form instead of a pro-form:

(3g) Wenn ein Mensch also von Leid getroffen wurde [sic], suchte [sic] er in seinen Überzeugungen, die sich aus Ideal, Religion, Philosophie und eben der [sic] Kultur speisten [sic], nach Antworten auf die „Warum? “-Frage des Leids und fand [sic] je nach seinen Überzeugungen unterschiedliche Antworten auf die „Warum?“-Frage. (LaRe)

Use of a pro-form whose referent is unclear:

(4g) Weiterhin [sic] war er ernsthaft daran interessiert [sic] die wichtigen afrikanisch-amerikanischen Fragen darzustellen und als "Schwarzer" [sic] Künstler deren Erfahrungen auszudrücken. (FrSc)

Missing coherence-generating element:

(5g) Wie auch immer du dich entscheidest, die Frage nach dem Leid ist für alle Menschen von höchster Bedeutung, daher ist es für dich persönlich wichtig, welche Antwort du dir selbst darauf gibst. (LaRe)

In excerpt $5 \mathrm{~g}$, it is supposed to be emphasized that die Frage nach dem Leid (Engl. the meaning of suffering) is important for all people, which is why it is also important that the reader finds an answer for himself. Without the inclusion of auch (Engl. also), the emphasis rather falls on dir selbst (it is important which answer you find for yourself).

Incorrect pro-form:

(6e) If the book is an aesthetic novel, then what is the function of the Gothic elements? It becomes clear when looking at both in close connection. (RiDö)

Isolated sentence that has no identifiable relation to what is stated before and/ or afterwards:

(7e) Nevertheless, "The Yellow Wall-Paper" is still relevant today since it shows the danger of a declining mental state due to a [sic] wrong or no treatment at all. This danger is also further reinforced. Being nameless, the story's protagonist can represent anyone. (LaSe)

(7g) Dennoch ist diese Kurzgeschichte auch heute noch relevant, da sie sehr eindrucksvoll beschreibt, was passieren kann, wenn depressiv erkrankte [sic] Menschen nicht oder falsch behandelt werden. Ein weiterer Abschreckungseffekt wird auch dadurch erzielt, dass die

10. For the complete English source texts and their translations, see Göpferich \& Nelezen (2012). 
Protagonistin von Perkin Gilmans Geschichte keinen Namen erhält und somit jeden Menschen wiederspiegeln [sic] kann. (LaSe)

In 7e, the italicized sentence simply has no apparent connection to the sentence following it. Its German counterpart $(7 \mathrm{~g})$, in contrast, also has no apparent relevance to the preceding content because of the use of the denotatively incorrect noun Abschreckungseffekt (deterrent) in combination with ein weiterer (a further), falsely signaling that a deterrent was already referenced in the preceding text.

Table 4 provides an overview of the absolute frequencies of each type of text-coherence error in the English and German texts. The values in parenthesis refer to those errors that were carried over from the English into the German texts, while the remaining errors are those which either could be avoided in the German texts or first appeared in them. The low values concerning English text-coherence errors carried over into the German texts and the high values concerning text-coherence errors first committed in the German texts demonstrate that, when it comes to verbalizing a text in another language, the relations of ideas that occur in the source text are not simply controlled by the formulations in the source text. Instead, the ideas are newly set in relation to each other during reverbalization. The result is that the ability to create coherence in a target text is not as likely to be affected by fixedness as rather seems to be the case in other areas of text composition (e.g., grammar and lexis). However, the fact that so many text-coherence errors still appeared in the German texts that are not the result of fixedness points to the need to address more thoroughly - in both the L2 and the L1 classroom-the methods for expressing logical relations between ideas. This can be achieved with translation exercises that take a contrastive approach to

\begin{tabular}{|l|c|c|}
\hline Text-coherence error type & English & German \\
\hline illogical connector & $13(3)$ & 8 \\
\hline inconsistent use of a correlative conjunction & - & 1 \\
\hline reference to an antecedent that does not fit & 1 & 3 \\
\hline use of a full form instead of a pro-form & - & 3 \\
\hline unclear referent & $2(1)$ & 2 \\
\hline missing coherence-generating element & - & 1 \\
\hline incorrect pro-form & 1 & - \\
\hline isolated sentence & $1(1)$ & 1 \\
\hline Totals & $18(5)$ & 19 \\
\hline
\end{tabular}

Table 4. Frequencies of text-coherence error types. 
creating coherent texts by means of, for example, connectors and pro-forms. For this purpose, writing instructors can create manipulated source texts with disturbed coherence, where the students' task is then to identify and rectify these areas of disturbed coherence during the translation process.

\subsection{Sense errors}

Sense errors occurred less often in the German texts than in their English counterparts (10 versus 4 respectively). Only one subject ( $\mathrm{FrSc}$ ) made a sense error in her German text that did not occur in the same place in her English text:

(8e) By capturing the spirit of his time in his works [sic] Douglas was among the first African Americans to explore their history and generating [sic] a common pride in their heritage, for instance [sic] by using symbols that represented their existing political rights. (FrSc)

(8g) Als einer der ersten afrikanischen Amerikaner [sic] entdeckte er die eigene Geschichte neu und entwickelte [sic] einen gemeinsamen Stolz auf das afrikanische Erbe, zum Beispiel ihre existierenden, politischen Rechte symbolisiert wurden.

The fact that the last portion of the sentence in $8 \mathrm{~g}$ fits neither syntactically nor contextually to what comes before it suggests that FrSc might have left it in by mistake; her keystroke log file reveals, however, that this information was in fact intentionally added on to this sentence, but that she struggled greatly in coming up with a German formulation with which she was satisfied. In comparing the different formulations FrSc considered, it can be assumed that she attempted to create as concise a sentence as possible but sacrificed all coherence to do so, which is probably a result of a lack of motivation to continue refining the sentence to express the intended meaning concisely.

In three cases, sense errors in the English source texts were simply reproduced in the target texts, while in three further cases, the English sentences with sense errors were simply omitted from the German texts, signaling perhaps a lack of comprehension of those sentences on the part of the subjects. These cases will not be further discussed here (but see Göpferich \& Nelezen 2012).

The following excerpts illustrate a case in which a subject was only first able to express herself clearly when writing in their Ll German:

(9e) In Lakoff's linguistic model [sic], a Democratic President [sic] as a 'Nurturant Parent' generally includes the population into the realm of the national decisive agents [sic] and resorts to the first person plural pronoun we. (InMa) 
(9g) In Lakoffs linguistischem Modell [sic] räumt ein demokratischer Präsident als „Fürsorglicher Versorger" den Bürgern des Landes entscheidende Mitspracherechte im nationalen Familienverbund ein und verdeutlicht dies durch die Benutzung des Pluralpronomens WE [wir].

The italicized portion of the sentence in excerpt 9e is incomprehensible, especially to those without a background in Lakoff's theory, for several reasons, including the polysemy of the word decisive, which can mean both (a) having the power or quality of deciding and (b) important, crucial. The author's thinkaloud protocol quoted below shows that she becomes aware of this problem once she has to produce a German version and is able to successfully correct it by selecting an expression that appropriately corresponds to the intended meaning, namely Mitspracherecht.

bürger in die: als decisive agents oh man die bürger als maßgebliche, naja, maßgeblich sind sie ja nicht, sie haben einfach nur, sie können mitreden und haben entscheidungsfreiheit oder zumindest ein mitspracherecht. als gleichwertig? und gleichwertig verantwortungsvolle, als mitspracheberechtigt? gibt es dieses wort? als mitspracheberechtigt in into the realm oh man die bürger als mitspracheberechtigt nein die bürger des landes oder gesteht ihnen mitspracherecht $z u$ ? räumt ihnen ein räumt () den bürgern des landes ein entscheidendes mitspracherecht ein, ein (1l. 381-394)

Later, the expression decisive agent occurs again in her English source text. This time, however, it refers to the president alone and should thus be rendered differently. Again, the author makes the right decision by rendering it this time as die entscheidende Autoritätsfigur. These two excerpts show that InMa was able to generate formulations in her German text that display a vast improvement in comprehensibility over her English version, pointing to the utility of translation to help students become aware of the important role their lexical choices have in text comprehensibility.

That fewer sense errors were made in German than in English, and that many of the errors in English were identified by the subjects and subsequently corrected in the German texts, gives further support to the assumption stated in section 2 that the subjects have a higher level of micro-level text-linguistic competence and are better able to differentiate semantically in their L1 than in their L2.

\subsection{Implicitness errors}

Implicitness errors occurred seven times in English and only two times in German. Remarkably, the two German errors were the result of their English counterparts being more or less directly transferred in the German texts, so 
the subjects were able to correct the five remaining source-text errors in their German texts. The two errors that recurred in the German texts were both made by the same subject, $\mathrm{JeCr}$, who reported being raised bilingually. Interestingly, this particular subject committed the highest number of errors of all subjects in her German text, and also had the second-highest number of errors in her English text. JeCr wrote her English source text with another subject in the experiment, FrSc, who was able to avoid both implicitness errors in her German rendering of the text. The following is an example of one such case:

(10e) Due to the past enslavement of African Americans, they were still believed to be uncultured and rough and were denied a cultural identity by White [sic] society. (JeCr and FrSc)

(10g1) Auf Grund der Versklavung der Afro-Amerikaner in der Vergangenheit [sic], [sic] wurden diese noch immer als unkulturell [sic] und ungebildet angesehen. Die weiße Bevölkerung glaubte, dass Afro-Amerikaner keine kulturelle Identität hätten. (JeCr)

(10g2) Die dominierende, [sic] weiße Gesellschaft hielt afrikanische Amerikaner [sic] für grob und kulturlos [sic], daher verweigerte sie ihnen die Anerkennung einer eigenen kulturellen Identität. Der Hauptgrund lag in der Versklavung von afrikanischen Amerikanern [sic] in der Vergangenheit [sic] und deren geringen Ansehen [sic] und [sic] Stellung in der damaligen [sic] Gesellschaft. (FrSc)

In 10e, a cause-and-effect relationship between the enslavement of African Americans and the 'white society's' subsequent opinion of them is established. Indeed, it could be argued that the relationship between the enslavement of African Americans and their reputation as "uncultured and rough" was actually the reverse of what is written in 10e: It was, among many other complex factors, these types of opinions about Africans in the United States that led to the social acceptance of their enslavement in the first place. Furthermore, the fact that white society had not substantially improved their view of African Americans at the beginning of the 20th century was not due to their enslavement itself but (at least partly) to the consequences of this enslavement. Certainly, former slaves and their children and grandchildren were by and large not given the opportunity to receive a high level of education and, due to a different cultural mentality, did not fit into what were considered at that time to be cultural norms. These factors led to an African American generation that was, for the most part, viewed as uneducated and uncultured.

In JeCr's German rendering of the text $(\log 1)$, she kept the relation between the two ideas - slavery and the view that African Americans were uncultured and rough - a causal one, not making further thoughts about it during the experiment. FrSc, in contrast, became aware during reverbalization that there 
was a problem with the sentence (TAP 1l. 680-690) and took measures to try and change it. Instead of establishing slavery the cause of this view, she made this view the cause of their being denied a cultural identity, a causality that is explicitly stated. Though FrSc's German text (10g2) does not, in the end, ideally describe the role of slavery in this situation, both the improvements in her text and her considerations while thinking aloud signal her ability to approach writing in her L1 more critically than she did in her L2.

In 11 there is another case in which the author (LaSe) was, in her German text, able to avoid the implicitness error she had made in her English text:

(11e) Though she is seriously ill, her husband and physician John does not trust her opinion and prescribes her a medication [sic] which insidiously worsens her condition. (LaSe)

(11g) Obwohl sie ihrer Meinung nach äußerst krank ist, sind alle ihre Bemühungen [sic] ergebnislos. Sie wird von ihrem Mann, der zugleich auch ihr Arzt ist, einfach nicht wahrgenommen [sic].

In 11 , it seems that the author wanted to express that the protagonist believed that she was seriously ill and made every effort to convince her husband of this, but that he, in spite of all her efforts, did not believe her. The conjunction though should thus not refer to the assertion that she was seriously ill but to her efforts to convince her husband, an assertion left implicit in this sentence. In $11 \mathrm{~g}$, the author is aware of the shortcomings of her expression of ideas in her English sentence and includes both ihrer Meinung nach (in her opinion) and Bemühungen (efforts) to make the relationship between the two statements more explicit; ideally, however, these efforts should have also been specified more closely (i.e., efforts to do what?).

The results concerning implicitness errors, i.e., that only one (bilingual) subject transferred these errors into her German text, while the rest of the subjects were able to avoid them, indicates that the cause of such errors may be the inability for the subjects to express themselves explicitly in a foreign language to the extent they can in their native tongue. As a type of avoidance strategy, perhaps, they may simply omit what they have difficulty expressing in their L2, negatively impacting the comprehensibility of these texts. This exclusion of content also has negative effects on the epistemic function of writing, as students do not practice expressing their ideas precisely and completely.

\subsection{Errors concerning functional sentence perspective (FSP)}

Of the three FSP errors that occurred in the English texts, two were corrected in the German versions, whereas one was simply taken over in the German 
text. ${ }^{11}$ This means that of the total six FSP errors in the German texts, five correspond with formulations in the English texts that are not erroneous. Consider first the two following errors that were avoided in the German texts:

(12e) So decide for yourself which paradigm sounds more convincing to you, as they will be explained more in detail in this article. (LaRe)

(12g) Diese beiden (Denk-)Muster werden im Folgenden genauer beschrieben, es ist an Dir [sic] zu entscheiden, welche der beiden Erklärungen dem Leiden mehr Sinn geben.

(13e) Women were often kept without love in a domestic sphere and not taken seriously by their husbands. The short story "The Yellow Wall-Paper" [sic] written in 1892 by Charlotte Perkins Gilman (1860-1935), an American writer, is an outstanding illustration of these attitudes and the treatment of 19 th $\mathrm{c}$. women. (LaSe)

(13g) Oftmals wurden an Depressionen erkrankte Frauen von ihren Ehemännern nicht wahrgenommen und $z u$ Hause einfach eingesperrt. Dies passiert auch in der Kurzgeschichte "The Yellow Wall-Paper" (im Deutschen: „Die gelbe Tapete“) aus dem Jahr 1892, welche von der amerikanischen Schriftstellerin Charlotte Perkins Gilman verfasst wurde.

In $12 \mathrm{e}$ and $13 \mathrm{e}$, information with relatively low communicative importance is presented at the prominent rheme position at the end of the sentence (italicized text). In $12 \mathrm{~g}$ and $13 \mathrm{~g}$, this information is now presented at an earlier position in the sentence. The expression in this article was rendered as im Folgenden, and the expression is an outstanding illustration... was quite smartly replaced with the deictic expression dies to refer back to the entire preceding sentence and to establish it as the topic of the new one. In both cases, the principle of theme-rheme is first instated in the German texts.

The case in 14 exemplifies an error by subject LaSe that, as mentioned in section 4, first occurred in the German text due to the imitation of the English word order. In German, the order in which the information about frequency and location is placed should have been adjusted to create the appropriate communicative dynamism.

(14e) Melancholia, burnout-syndrome [sic], depression - mental diseases seem to be increasingly common in today's society. (LaSe)

(14g) Melancholie, Burnout-Syndrom sowie Depressionen - physische [sic] Krankheiten treten immer häufiger in unserer Gesellschaft auf.

11. This error is not addressed here due to reasons of space. A side-by-side comparison of all the text-level errors in English and German can be found in the data documentation in Göpferich \& Nelezen (2012). 
The error in $14 \mathrm{~g}$ seems to be the result of interference from the English source text. In other words, the task of translating itself may have caused the subject to create a German text with syntactical structures the subject, in a free writing situation, would not have created. The error in 15 also very likely occurred because of the translation task.

(15e) Due to the past enslavement of African Americans, they were still believed to be uncultured and rough and were denied a cultural identity by White [sic] society. (FrSc)

(15g1) Der Hauptgrund lag in der Versklavung von afrikanischen Amerikanern in der Vergangenheit und deren geringen [sic] Ansehen und [sic] Stellung in der damaligen Gesellschaft.

The author's TAP (1l. 640-687) reveals that she struggled greatly with finding an appropriate German equivalent for the modifier past, attempting several times in vain to incorporate a pre-nominal modifier before finally settling upon in der Vergangenheit, yet still apparently dissatisfied with the result of the sentence. Though semantically correct, the post-nominal position of in der Vergangenheit places undue weight on its communicative importance in the sentence; rather, the emphasis should be placed on Versklavung ('enslavement') as could easily be achieved in English by the placement of past before slavery. One possible solution might have been to express the enslavement in verbal form, as in $15 \mathrm{~g} 2$.

(15g2) Der Hauptgrund lag darin, dass die Afro-Amerikaner in der Vergangenheit versklavt worden waren ...

Such errors could also be the result of fixedness on the wording in source texts, which, as mentioned in section 4 , often occurs among translation novices lacking translation competence. If this is the case, then half of the FSP errors in German (three of six) can be attributed to this cause. In contrast, the FSP error in excerpt 16, which occurred in the first sentence, cannot be ascribed to fixedness.

(16e) The United States of America is the land where revolutions are born. Aside from politically motivated ones ..., important cultural revolutions derive [sic] their origin from America. (FrSc)

(16g) Viele Revolutionen wurden in den Vereinigten Staaten von Amerika geboren. Eine dieser Revolutionen war in der Lage ...

Here, the subject did not imitate the word order in the English text but intentionally altered it in the target text. Because revolutions being born is the new information being introduced in this sentence - and is also taken up as the topic of the subsequent sentence in linear progression - it should 
have appeared, as it did in the English sentence, at the sentence-final rheme position.

The TAP of the author of $16 \mathrm{~g}$ clearly reveals her motivation behind diverting from the word order in the source text: Though she generated alternatives that included the revolutions both at the beginning and at the end of this sentence, she was apparently preoccupied with other aspects of the sentence with which she was not satisfied, namely the verb phrase geboren werden and the relative pronoun wo:

the united states of america is the land where revolutions are born. $\mathrm{OH}$, noch ein kurzer. würde aber ein bisschen umstellen. ich würde, glaube ich, schreiben ehm also statt in: in den vereinigten staaten von amerika werden revolutionen geboren, obwohl das sich auch nicht schlecht anhört, ich schreibe, glaube ich, beides mal hin. also in den vereinigten staaten von amerika werden ist das, die vereinigten, also übersetzt wäre es ja ganz genau die vereinigten staaten von amerika ist das land, wo revolutionen geboren werden. machen wir erst mal ups, da gehörst du nicht hin, das ist die vereinigten staaten von amerika ist ... ist das land, wo revolutionen geboren werden ... so. das mit dem wo gefällt mir nicht ... soh:, man könnte auch umstellen, in revo nicht die, man könnte ja auch die revolutionen nach vorne machen. viele revolutionen ehm wurden in den vereinigten staaten von amerika geboren? vielleicht finde ich noch etwas anderes für geboren. in den viele revolutionen wurden in den vereinigten staaten von amerika geboren. dann gebo:ren. geboren okay, das ist kürzer, ich habe diesen blöden, langen satz nicht drin. (ll. 197-222)

The author's neglect of the requirements of this sentence's communicative dynamism in this case might indicate a lack of awareness for such requirements. In general, the fact that the subjects do not seem to be aware of the principles underlying the arrangement of words from a communicative standpoint may be the cause of their lack of resistance to interference in this area of text grammar. It can be assumed that such errors could be avoided with the help of focused instruction concerning FSP. Topic-comment structures are not a part of the German school curriculum, so it is all the more important to address FSP in writing classes at higher education institutions. This can be accomplished in a contrastive manner, with, for example, translation exercises in which target-text versions require an adaptation of word order due to the requirements of communicative dynamism.

\section{Summary and conclusion}

This study compared the quality of L2 (English) popular-science texts with that of their L1 (German) versions written by the same authors. In this analysis, special attention was paid to the following text-level error categories: 
coherence, sense, implicitness, and FSP. The data used for analysis included not only the written products but also process-oriented data collected using think-aloud and keystroke logging. The specific characteristics of the German products as resulting from the translation task itself were given special focus.

The comparison of the text-level writing competence of the six advanced English students revealed that, while fewer sense and implicitness errors were made when subjects wrote in their Ll, there was no significant difference in the total number of text-coherence errors between L2 and L1, and FSP errors occurred even more frequently in the $\mathrm{L} 1$ than in the $\mathrm{L} 2$. The lattermost result, as well as the overall result that more linguistic errors occurred in German than in English, can be primarily attributed to the translating task, i.e., many errors in German would likely have not occurred without the presence of the English source texts they were based on. It can be assumed that, due to the low level of translation competence among the subjects in this study, they did not resist interference and tended to display fixedness on the source text, phenomena which might not have occurred during a free text-production task. Fixedness and interference thus represent disadvantages of translation tasks that must be taken into account when assessing text-production competence in two languages on a contrastive basis using translation tasks as writing assignments.

During translation, the source text alleviates the cognitive demand of the task at hand because the content of the source text can be taken over into the target text. In line with McCutchen's (1996) capacity theory of writing, this decrease in cognitive demand can be assumed to free up working memory capacity that can then be dedicated to other text production processes. This may also lead to target texts that, in certain aspects, are better than those produced without a source text. Such observations were made, for example, by Uzawa (1996) in her study of 22 university students who had to complete three writing tasks: one writing task in their L1 (Japanese), one in their L2 (English), and one translation of a completed L1 text into their L2. These students were-in both their L1 and L2 - inexperienced writers who could not devote sufficient attention to the linguistic quality of their freely written texts. That is, according to Bereiter \& Scardamalia (1987; see also Kellogg 2008), they were in the first stage of writing development, called knowledge telling. Their translations, in contrast, were higher in linguistic quality than their L2 texts. This may be attributed to the fact that the translation task relieved the subjects of extensive planning processes, resulting in more attention available for linguistic details. 
Aside from methodological disadvantages for determining text-production competence, translation tasks also have many advantages, especially when a product-oriented approach is combined with a process-oriented one. In many cases, process-oriented data make it possible to determine whether the subjects are aware of the errors and other shortcomings in their source texts and, if so, whether they are able to improve upon these in their target texts. In this study, this was witnessed for implicitness and sense errors, indicating a greater degree of linguistic flexibility in their $\mathrm{Ll}$ and a more restricted competence in their L2. In turn, this limited flexibility in expressing themselves in their L2 may prove to be harmful to the epistemic function of writing, as this limitation could lead to newly-formed knowledge never fully-or only distortedly-expressed in writing, which is harmful to the development and refinement of knowledge.

This study has also shown that translating can be a useful tool in the didactics of writing. Through translation, students can practice writing with a reduction in complexity, particularly on the macro-level, as the source text already provides the contents to be composed in verbalized form, allowing the students to pay greater attention to micro-level subtleties they might have otherwise ignored. Kim (2011) also corroborated this advantage of translation; she found that having her students translate from their L1 into their L2 enabled them to evaluate their L2 texts more critically. On top of gaining a greater awareness of structural differences between their L1 and L2, students are also more sensitized to language-specific requirements from a communicative standpoint, such as those of sentence construction. Specially-tailored translation tasks can furthermore facilitate students' awareness of language-specific coherence-generating means; for example, having them translate using a source text in which connectors are systematically deleted would force them during their translation processes to think about the logical relations between two parts of a sentence or two sentences and how to express them appropriately in each language. In this way, students are prompted to express explicitly certain relationships in written form that are significantly more difficult to establish and monitor in free writing tasks.

Due to its small scope, no generalizations can be made on the basis of this study. The results, however, demonstrate the interesting insights that an analysis of text-level errors can bring to our knowledge about text-composition competence, and lead us to conclude that a study with greater scope concentrating on the creation of text coherence in writing would bring even more promising insights into the development of writing competence. An especially interesting research question to explore would be whether or not 
writing competence correlates with the ability to receptively detect certain types of errors, and whether or not the quality of texts on a text-linguistic level, as was determined here by the errors on the text level, can serve as a reliable predictor of the general text-production competence of a particular author.

\section{References}

ARNDT, Valerie. (1987) "Six writers in search of texts: A protocol-based study of L1 and L2 writing." ELT Journal 41:4, pp. 257-267.

BEREITER, Carl \& Marlene Scardamalia. (1987) The Psychology of Written Composition. Hillsdale, NJ: Lawrence Erlbaum.

Clark, Andy. (1998) Being There: Putting Brain, Body, and World Together Again. Cambridge, MA: MIT Press.

Clark, Andy. (2008) Supersizing the Mind: Embodiment, Action, and Cognitive Extension. Oxford: Oxford University Press.

Clark, Andy \& David J. Chalmers. (1998). "The extended mind.” Analysis 58:1, pp. 7-19.

Cumming, Alister. (2001) "Learning to write in a second language: Two decades of research." International Journal of English Studies 1:2, pp. 1-23.

Devine, Joanne; Kevin Railey \& Philip Bischoff. (1993) "The implications of cognitive models in L1 and L2 writing." Journal of Second Language Writing 2:3, pp. 203-225.

DunCKER, Karl. (1945) “On problem-solving." Psychological Monographs 58:5: pp. 1-114.

GÖPFERICH, Susanne. (1995) Textsorten in Naturwissenschaften und Technik. Pragmatische Typologie - Kontrastierung - Translation. Tübingen: Narr.

GÖPFERICH, Susanne. (2002) "Ein kommunikationsorientiertes Modell zur Bewertung der Verständlichkeit von Texten." In: Strohner, Hans \& Roselore Broose (eds.) 2002. Kommunikationsoptimierung: verständlicher - instruktiver - überzeugender. Tübingen: Stauffenburg, pp. 45-66.

GÖPFERICH, Susanne. (2006) "How successful is the mediation of specialized knowledge? - The use of thinking-aloud protocols and log files of reverbalization processes as a method in comprehensibility research." HERMES 37, pp. 67-93.

GÖPFERICH, Susanne. (2010) "Data documentation and data accessibility in translation process research." The Translator 16:1, pp. 93-124.

GÖPFERICH, Susanne \& Bridgit Nelezen. (2012) "Data documentation for the article "The language-(in)dependence of writing skills: Translation as a tool in writing process research and writing instruction'." 
Electronic version available at: <http://www.susanne-goepferich.de/ Data_Documentation_Writing_L1_L2.pdf>

GÖPFERICH, Susanne \& Bridgit Nelezen. (2013) "Die Sprach(un)abhängigkeit von Textproduktionskompetenz: Translation als Werkzeug der Schreibprozessforschung und Schreibdidaktik." ZfAL - Zeitschrift für Angewandte Linguistik 58:1, pp. 167-200.

HutChins, Edwin. (1995) Cognition in the Wild. Cambridge: MIT.

KellOGG, Ronald. (2008) "Training writing skills: A cognitive developmental perspective." Journal of Writing Research 1:1, pp. 1-26. Electronic version available at: <http://jowr.org/articles/voll_1/JoWR_2008_voll_nrl_Kellogg. pdf>

KIM, Eun-Young. (2011) "Using translation exercises in the communicative EFL writing classroom." ELT Journal 65:2, pp. 154-160.

KoHRO, Yoshifumi. (2009) "A contrastive study between L1 and L2 compositions: Focusing on global text structure, composition quality, and variables in L2 writing." Dialogue 8, pp. 1-19. Electronic version available at: <http://talkwaseda.net/dialogue/no08_2009/2009dialogue08_k1.pdf>

MANDELblit, Nili. (1995) "The cognitive view of metaphor and its implications for translation theory." In: Lewandowska-Tomaszcyk, Barbara \& Marcel Thelen (eds.) 1995. Translation and Meaning, Part 3. Maastricht: Hoogeschool Maastricht, pp. 483-495.

MCCUTCHEN, Deborah. (1996) "A capacity theory of writing: Working memory in composition." Educational Psychology Review 8:3, pp. 299-325.

ROCA DE LARIOS, Julio; Rosa M. Manchon \& Liz Murphy. (2006) "Generating text in native and foreign language writing: A temporal analysis of problem-solving formulation processes." The Modern Language Journal 90:1, pp. 100-114.

SCHOONEn, Rob; Amos van Gelderen; Kees de Glopper; Jan Hulstijn; Annegien Simis; Patrick Snellings \& Marie Stevenson. (2003) "First language and second language writing: The role of lingusitic knowledge, speed of processing, and metacognitive knowledge." Language Learning 53:1, pp. 165-202.

SILVA, Tony. (1992) "L1 vs. L2 writing: ESL graduate students' perceptions." TESL Canada Journal 10:1, pp. 27-47. Electronic version available at: <http://www. eric.ed.gov/PDFS/EJ457628.pdf>

WHALEN, Karen \& Nathan Menard. (1995) "L1 and L2 writers' strategic and linguistic knowledge: A Model of multiple-level discourse processing." Language Learning 45:3, pp. 381-418.

UzAWA, Kozue. (1996) "Second language learners' processes in L1 writing, L2 writing, and translation from L1 into L2." Journal of Second Language Writing 5:3, pp. 271-294. 


\section{BIONOTES / KURZVITAS}

Susanne Göpferich is Professor of Applied Linguistics at the Department of English and Director of the Centre for Competence Development (ZfbK) at Justus Liebig University in Giessen, Germany. From 1997 to 2003 she was Professor of Technical Communication and Documentation at the Karlsruhe University of Applied Sciences (Germany), and from 2003 to 2010 Professor of Translation Studies at the University of Graz, Austria. Her main fields of research and publication comprise text linguistics, specialized communication, translation and transfer studies, comprehensibility research as well as writing and translation process research with a focus on competence development as well as writing and translation pedagogy. Website: <http://www. susanne-goepferich.de>

Susanne Göpferich ist Professorin für Angewandte Linguistik am Institut für Anglistik und Direktorin des Zentrums für fremdsprachliche und berufsfeldorientierte Kompetenzen (ZfbK) der Justus-Liebig-Universität Gießen. Von 1997 bis 2003 hatte sie eine Professur für Technische Kommunikation und Dokumentation an der Hochschule Karlsruhe Technik und Wirtschaft inne, von 2003 bis 2010 einen Lehrstuhl für Translationswissenschaft an der Karl-Franzens-Universität Graz. Zu ihren Forschungs- und Publikationsschwerpunkten gehören die Textlinguistik, die Fachkommunikationsforschung, die Übersetzungs- und Transferwissenschaft, die Verständlichkeitsforschung sowie die Schreib- und Translationsprozessforschung, wobei ihr besonderes Interesse Fragen der Kompetenzentwicklung sowie der Translations- und Schreibdidaktik gilt. Website: <http://www.susanne-goepferich.de>

Bridgit Nelezen received her B.A. in Linguistics, Political Science, and International Studies from the University of Wisconsin-Milwaukee in 2006 and went on to earn an M.A. in Modern Languages and Linguistics from Justus Liebig University in Giessen in 2012. Since earning her B.A., she has been teaching and researching English and Applied Linguistics in various forms and is currently a lecturer at the Department of English at Justus Liebig University. Her research interests include approaches to teaching English for specific purposes as well as second language writing in higher educational and business settings. 
Bridgit Nelezen schloss 2006 ihr Bachelorstudium an der University of Wisconsin-Milwaukee in den Fächern Linguistik, Politik und internationale Beziehungen ab und absolvierte 2012 ein Masterstudium der Fachrichtung „Moderne Sprachen und Sprachwissenschaft" an der Justus-Liebig-Universität Gießen. Sie unterrichtet und forscht auf dem Gebiet der englischen Sprache sowie der Angewandten Linguistik und ist derzeit als Lektorin am Institut für Anglistik der Justus-Liebig-Universität tätig. Ihre Forschungsinteressen umfassen englische Fachsprachendidaktik sowie L2-Schreibforschung im universitären und beruflichen Kontext. 